\title{
Institutional Investors and Executive Compensation
}

\author{
by \\ Jay C. Hartzell ${ }^{\boxplus}$ \\ New York University \\ Stern School of Business \\ 44 West $4^{\text {th }}$ Street, Suite 9-190 \\ New York, NY 10012 \\ (212) 998-0359 \\ Fax: (212) 995-4233 \\ jhartzel@stern.nyu.edu \\ and \\ Laura T. Starks \\ University of Texas \\ Department of Finance \\ Austin, TX 78712-1179 \\ (512) 471-5899 \\ FAX: (512) 471-5073 \\ Istarks@mail.utexas.edu
}

July 2000

\footnotetext{
${ }^{\dagger}$ We would like to thank seminar participants at Carnegie-Mellon University, Marquette University, the New York University-Columbia University joint seminar, Washington State University, the Wharton School, the University of Texas at Austin and the FMA European Meetings in Edinburgh for their useful feedback. We benefited from the comments and suggestions of Renee Adams, Andres Almazan, Nemmara Chidambaran, Matt Clayton, John Core, Roger Edelen, Zsuzsanna Fluck, Wayne Guay, Stuart Gillan, Ron Shrieves, Richard Sias, Sheridan Titman, and David Yermack. We would also like to thank Murat Binay and David Weinbaum for valuable research assistance.
} 


\title{
Institutional Investors and Executive Compensation
}

\begin{abstract}
Due to institutional investors' increasing ownership and interest in corporate governance, we hypothesize that the presence of institutional investors is associated with certain executive compensation structures. We find a significantly negative relation between the level of compensation and the concentration of institutional ownership, suggesting that institutions serve a monitoring role in the shareholder-manager agency problem. We further find a significantly positive relation between the pay-for-performance sensitivity of executive compensation and both the level and concentration of institutional ownership. These results suggest that the institutions act as a complement rather than a substitute to incentive compensation in mitigating the agency problem.
\end{abstract}




\section{Institutional Investors and Executive Compensation}

As their ownership of corporations has grown over the last few decades, the monitoring role of institutional investors in corporate governance has become more important. One area in which this monitoring has focused is in the incentives provided for top management through compensation contracts. Activist institutional investors have publicly proclaimed their interest in this area for some time. For example, CaIPERS, among other public pension funds, maintains that managerial compensation should be tied to the performance of the firm (Colvin (1992)). In addition, private money managers, such as Fidelity Investments, have voiced their intent to vote against stockrelated compensation plans if they are unfair to other shareholders or do not provide management with sufficient incentives to boost financial performance (Pulliam (1993)).

Given the increasing interest in managerial compensation by institutional investors along with their increasing dominance in equity markets, one would expect institutional investor presence in a firm to be associated with certain executivecompensation structures. The relation could develop from two sources. The first, direct intervention such as that practiced by activist institutions like CaIPERS, occurs when the institutional owners pressure boards of directors to limit excess compensation and to adopt certain compensation structures such as pay for performance. The second source of influence is indirect and develops through institutional trading and preferences for firms with better corporate governance characteristics. Because of these preferences, firms that want to attract institutional investors would adopt compensation schedules that they believe will be appealing to the prospective institutional owners.

Two competing hypotheses exist to explain an interactive role between institutional investors and incentive compensation in mitigating the agency problem between managers and shareholders. The first hypothesis considers that the presence of institutional investors as monitors of the firm can substitute for some of the managerial incentive compensation. That is, given more monitoring, the firm does not have to expend as many resources on managerial compensation. The second hypothesis considers the monitoring by institutional investors to be complementary to the incentive 
compensation. That is, the monitoring by institutions works in concert with managerial compensation to mitigate the agency problem.

In this paper, we test for a relation between executive compensation and institutional investor influence and whether such a relation is due to a substitution or complementary effect. We measure direct institutional influence by the concentration of institutional ownership in a firm and indirect influence by the level of aggregate institutional ownership. We find strong evidence of a relation between each of these measures of institutional influence and both the level and performance-sensitivity of executive compensation. Most important, we find a negative relation between institutional concentration and level of executive compensation and a positive relation between both measures of institutional influence and the pay-for-performance sensitivity of managerial compensation. The latter result suggests that institutional investors act as a complement rather than a substitute for incentive compensation.

Our study differs from earlier studies on managerial compensation in that we examine the interaction between compensation structure and one particular type of corporate governance control that has not been previously studied with regard to managerial compensation - the presence and concentration of institutional investors. In addition, we examine pay-for-performance of the entire top management team as well as that of the CEO. Much of the prior research has restricted its focus to CEOs.

The paper is organized as follows. In the next section, we discuss the importance of incentive compensation for managers and the role of institutional investors as monitors of management. We also develop our two competing hypotheses regarding the effects of institutional investor influence on managerial compensation. After describing the data in Section II, we test the relation between institutional influence and the measures of compensation in Section III. We provide our conclusions in the final section. 


\section{Managerial Incentive Compensation and Institutional Investor Monitoring}

An agency problem exists between a firm's shareholders and its management because they do not have the same goals and preferences; managers have the natural incentive to make decisions in their own best interests rather than those of the shareholders. As pointed out by Fama and Jensen (1983), the shareholder-manager agency problem can be mitigated through a number of different monitoring mechanisms, such as the stock market, institutional investors, large blockholders, board of directors, labor, lenders, the legal and regulatory environment, and the effects of the informational and competitive environment. An additional mechanism (chosen by the board of directors) derives from the incentive compensation of managers.

We focus on the interrelation between two of the potential monitoring mechanisms, managerial incentive compensation and institutional investors. It should be recognized, however, that the other mechanisms also likely influence this interrelation. For example, the legal and regulatory environment imposes constraints not only on the actions of the institutional investors, but also on the form and level of executive compensation.

A number of studies examine the consequences of incentive compensation in an agency relationship. Principals, such as the shareholders of a corporation, have a variety of potential methods of compensating their agents, the managers. For example, in addition to straight wages or deferred payments, compensation can depend on the manager's performance through the use of bonus pay, stock grants, or option grants. Such compensation is consistent with theoretical arguments, e.g., Holmstrom (1979) and Shavell (1979), which show that in the presence of moral hazard problems, optimal payoffs to the agent are contingent on performance. The relation of compensation to firm performance (the pay-for-performance sensitivity ff compensation) has also been documented by a substantial body of empirical work. ${ }^{1}$ Beyond the slope of the performance sensitivity of managerial pay, studies have also examined how managerial

\footnotetext{
${ }^{1}$ See Murphy (1998) for an extensive review of this literature.
} 
decisions can be influenced through the convexity of that pay to performance (e.g., Smith and Stulz (1985), Guay (1999)).

Because of the potential complexity of executive compensation and its effects on managerial decisions, studies have shown that the components of the compensation contract can have diverse effects, depending on the risk aversion and/or wealth of the manager (Carpenter (1999), Ross (1999)). Given these diverse potential effects, one would not expect incentive compensation to be the sole mechanism for mitigating agency problems between managers and shareholders, implying that other mechanisms - such as monitoring by institutional investors - would also be needed.

\section{I.A. Institutional investors as monitors}

Institutional investors can directly monitor firms through public or private activism. That is, the institution can directly let management know of their preferences and perspectives and can put pressure on management to follow their suggestions or directives. Alternatively, institutional monitoring can arise indirectly through institutional preferences for firms with certain corporate governance characteristics such as better compensation practices. Both the direct and indirect methods of monitoring may have effects on the compensation structures of corporate executives.

\section{I.A.1. Direct institutional monitoring}

As noted in the introduction, private and public fund managers have voiced their opinions that managerial compensation should be linked to corporate performance. With regard to the public funds, Smith (1996) documents that CalPERS shareholder resolutions include restructuring executive compensation. Further, in an examination of 2,042 shareholder proxy proposals over an eight-year period, Gillan and Starks (200ק) find that 233 of these proposals were specifically related to executive compensation. ${ }^{2}$ Although most of these specific compensation proposals were submitted by individual

\footnotetext{
${ }^{2}$ Johnson and Shackell (1997) and Johnson, Porter, and Shackell (1997) investigate the executive compensation shareholder proposals in depth.
} 
rather than institutional investors, the latter have focused on corporate governance issues with indirect effects on executive compensation. For example, Gillan and Starks find that a major issue of institutional investors has been increased director independence for the board, particularly on the board's nominating and executive compensation subcommittees. Further evidence of the institutions' concern about executive compensation is reflected in the fact that an institutional investor advisory service, Institutional Shareholder Services, lists one of their services as voting recommendations on executive compensation shareholder proposals in a firm's proxy statement.

Beyond the evidence regarding public institutional investor involvement in corporate governance issues, there are also indications of non-public institutional influence. For example, Useem (1996) provides anecdotal evidence concerning the chief executive and chief counsel of a corporation meeting several times with one of their major pension fund investors to discuss revising the corporation's managerial compensation structure. Useem goes on to state, "As companies have increased the contingency of their senior managers' compensation, the marching orders from the investment community have been to tighten the linkage with shareholder wealth."

As large shareholders, institutional investors have the ability and the incentive to be significant direct monitors of managerial actions. Due to the high costs of monitoring and the fact that all shareholders would benefit from the monitoring, only large shareholders who could achieve substantial benefits have the incentive to monitor (e.g., Grossman and Hart (1980), Shleifer and Vishny (1986), Huddart (1993)). However, institutional investors' ability and incentives to monitor conflict with the goal of many institutions to maintain liquidity in their holdings. That is, to achieve the benefits necessary to justify the monitoring costs, institutional investors would likely forgo the ability to quickly liquidate. According to some authors (Coffee (1991), Bhide (1994)), institutions are more concerned about the liquidity of their investments than building up the concentrated ownership that would be required to have an influence on corporate decisions. In fact, Bhide argues that the strong liquidity of U.S. markets actually 
impedes institutional involvement in corporate governance because it is less costly for the institutions to sell the firms that are in need of active involvement. If liquidity costs were higher, institutions would have a greater monitoring incentive.

Kahn and Winton (1998), Noe (1998), and Maug (1998) derive models to consider the institutional investors' tradeoffs between liquidity and control. According to Kahn and Winton, institutions must explicitly consider the tradeoff because the profits from speculation are directly affected by the costs of monitoring (which consist of more than the direct intervention costs). They show that an institution's decision on active management depends on firm characteristics that influence whether the benefits of increasing the value of the institution's holdings in the firm outweigh the costs to the trading profits. According to Noe's analysis, institutional investors are motivated to monitor managers because they can gain from the monitoring, even in the presence of free-rider problems, costly monitoring, and lacking any initial stake in the corporation. Maug argues further that the impact of liquidity on the control of a firm can actually be positive. Although liquid stock markets make it easier to sell a large ownership position, they also make it easier for investors to build up large positions in a firm and profit from increasing their monitoring activities.

There is a difference between the monitoring incentives and abilities of institutional investors and large blockholders that are not institutions. Gorton and Kahl (1999) differentiate between these two types of investors and point out that the institutional investors provide imperfect monitoring due to their own internal agency problems. Because there are not sufficient individual large blockholders to provide the better monitoring, however, the imperfect monitoring of institutional investors is still beneficial.

It should also be recognized that even within the institutional category, the monitoring is expected to vary due to the institutions' diverse clienteles, preferences, goals, and constraints. Brickley, Lease and Smith (1988) discuss the difference between pressure-sensitive and pressure-insensitive institutional shareholders and argue that the former type of institution would be more likely to go along with 
management decisions because they have current or potential business relations with the firm. The authors find evidence consistent with their hypothesis - firms with greater holdings by pressure-sensitive shareholders have more proxy votes in line with management's recommendations and firms with greater holdings by pressure-insensitive shareholders experience more proxy votes against management's recommendations.

Borokhovich, Brunarski, and Parrino (2000) provide evidence consistent with both the Gorton and Kahl (1999) and the Brickley, Lease and Smith (1988) hypotheses. In their study of announcement effects for antitakeover amendments, Borokhovich, Brunarski and Parrino find that the sign of the relation between the abnormal return around the announcement and the percentage of outside blockholdings depends on the identity of the blockholder. When the blockholders are either individuals or pressureinsensitive institutions (investment companies or independent investment advisers), abnormal return and percentage blockholdings are significantly positively related. When the blockholders are pressure-sensitive institutions such as banks or insurance companies, the two variables are significantly negatively related. ${ }^{3}$

Besides the size of their holdings, a further issue with regard to the presence of institutional investors is their potential collaboration. Black (1992) submits that institutions should be allowed to increase their monitoring power by holding larger stakes in companies and teaming up with other institutional investors in order to be a more important factor in corporate governance. Holmstrom's (1982) model of contracting shows that large shareholders (concentration of ownership) may be needed to enact the optimal contract with agents. ${ }^{4}$ Thus, according to Black and to Holmstrom's presumptions, we would expect to see better monitoring in corporations that have a larger concentration of institutional investor ownership, ceteris paribus.

\footnotetext{
${ }^{3}$ Borokhovich, Brunarski and Parrino (2000) use the terms affiliated and unaffiliated rather than pressure sensitive and pressure insensitive.

${ }^{4}$ For a review of papers with implications for owner concentration, see Allen and Winton (1995).
} 


\section{I.A.2. Indirect Institutional Monitoring}

Rather than occurring through direct pressure from large or concentrated shareholdings, monitoring by institutional investors can also occur indirectly through their preferences and trading. For some institutional investors, their high turnover would seem to imply that monitoring is not a central focus of their strategies. However, if the portfolio managers' investment decision algorithm considers quality of management, and in turn, executive compensation practices, then an outcome of even actively-traded managers' decisions is that greater institutional investment will be associated with better executive compensation practices. Evidence on this comes from a survey of mutual fund managers in which $58 \%$ stated that their investments are influenced by the level of CEO pay, and $71 \%$ stated that they are favorably influenced by stock-based pay plans. Further, about $87 \%$ indicated that they are positively influenced, at least sometimes, when a company has a stated policy on stock ownership for top executives, $90 \%$ review the compensation and options tables in companies' annual proxy statements, and about $49 \%$ review the letter from the Board's Compensation Committee, which usually describes a company's compensation philosophy and explains its compensation programs (Maxey and ten Wolde (1998)).

Further evidence on the effects of institutional investor preferences comes from the Gompers and Metrick (1999) study in which they argue that institutional investor preference for large firms along with their increasing presence in equity markets has affected relative stock prices between large and small firms.

Indirect influence arises also when institutions choose to sell their shares rather than attempt to instigate change in the firm. Such selling can have an ultimate impact on the corporation's governance through several potential effects: downward price pressure due to supply-demand effects, information signals to other investors, and changes in shareholder composition. The first effect is supported by empirical evidence that shows heavy institutional selling can put downward pressure on the stock price (e.g., Brown and Brooke (1993), Sias, Starks, and Titman (2000)). Alternatively, information effects that arise from institutional selling can affect the stock price, causing other investors to 
sell as well. Finally, the type of institutional investor holding the shares may change. This last effect may be important to directors if the type of institution holding the stock affects share value and/or management of the company. The directors may want to attract a particular type of institution as shareholders, for example, institutions that have a longer-term focus (Bushee and Noe (1999)), institutions that are more likely to vote with management (Brickley, Lease and Smith (1988)), or institutions that provide the firm with greater credibility (Allen, Bernardo and Welch (2000)). Hotchkiss and Strickland (2000) find that the market reaction to a firm's earnings announcements depends on the composition of the institutional investors holding their shares. Further, John and John (1993) argue that it may be optimal for the board to consider the total effects of the compensation structure, including the effects on other stakeholders in the firm.

Evidence on the effects of institutional selling is provided by an empirical study by Parrino, Sias and Starks (2000). They find that firms that fire their top executives have a significantly greater decline in institutional ownership in the year prior to the CEO turnover than do firms that experience voluntary CEO turnover. These results are consistent with the hypothesis that institutional selling influences decisions by the board of directors - institutional selling of a stock increases the likelihood a CEO is forced from office. ${ }^{5}$ Further, they find that the institutional selling is associated with whether the board chooses an inside or outside replacement for the CEO. ${ }^{6}$

\section{I.B. Interrelation between Institutional Investor Monitoring and Incentive Compensation}

The implications of the previous theoretical and empirical research are that both institutional investors and managerial incentive compensation serve to help control the shareholder-manager agency problem. As Jensen (1993) argues, diverse monitoring mechanisms can work together in controlling corporate management. The question is whether the different mechanisms act as complements or substitutes. Pound (1992)

\footnotetext{
${ }^{5}$ As noted by the authors, these results are also consistent with the hypothesis that institutional investors are better informed than other investors, and thus become net sellers over the period prior to forced turnovers when these firms typically experience negative market-adjusted returns. ${ }^{5}$ Bushee (1998) and Wahal and McConnell (1999) also provide evidence of apparent institutional monitoring in $R \& D$ expenses and capital expenditures.
} 
suggests that the different mechanisms change to substitute for each other when one mechanism, such as the takeover market, begins to wane. Providing an example of substitutes for incentive compensation, Hartzell (1999) shows that the threat of termination and career concerns act as substitutes for the incentives provided by pay for performance.

In our case, if institutional investors act as a substitute for incentive compensation, then they provide monitoring for the firm (either directly or indirectly) that offsets the need for assumedly costly incentive compensation. That is, the presence of institutional investors ameliorates the moral hazard problem between owners and managers; consequently, there is less need to employ incentive compensation as a quasi-monitoring device. For example, suppose the monitoring by institutional investors is indirect, but that they are informed investors. The board of directors could then infer additional information about the firm from its stock price and from institutional investor trading behavior.

Alternatively, institutional investors could be a complementary monitoring device, in which case their role adds to that of incentive compensation. Holmstrom and Tirole (1993) consider the needed interaction between stock market monitoring (in our case, institutional investors) and managerial incentive compensation, arguing that neither mechanism is sufficient alone to perfectly monitor managers. Under the hypothesis that institutional investors are complements to incentive compensation, the presumption is that some firms have larger agency problems than do other firms. For example, the firms are in industries in which managers have larger potential effects on firm performance, but the managerial actions are less observable. In such firms, there is a need for greater disciplinary measures which may take the form of greater monitoring by institutions as well as greater incentive compensation.

An analysis predicting such a complementary relationship is that of Chidambaran and John (1999), who model relationship investing in an asymmetric-information setting. In their model, managers have information about the future value of projects that investors do not have. Further, managers are motivated to attend to the firm's current 
market value rather than its future value. Institutional investors can help resolve this information asymmetry, but at a cost. Through incentive compensation that links managerial pay to firm performance, managers would be willing to cooperate with the institutional investors. These factors together help mitigate the agency problems between shareholders and managers. The theory suggests that for sufficiently severe agency problems, in equilibrium, institutional owpership and incentive pay tied to the future value of the firm should be complements. ${ }^{7}$

The substitute and complement hypotheses imply differences in the sign of the relation between institutional influence and the pay-for-performance sensitivity of executive compensation. Specifically, consider the case where institutions act as a substitute monitoring device for incentive compensation. Assuming that it is costly to provide incentives to managers through compensation contracts, if institutions act as a substitute, then managers of firms with more concentration of institutional ownership should have lower pay-for-performance sensitivities, everything else equal. In contrast, if the institutions are a complementary device, then managers of firms with more concentration of institutional ownership should have higher pay-for-performance sensitivities.

\section{Data}

We begin to form our sample by selecting the 1,914 firms included on the Standard \& Poor's ExecuComp database over the 1991 through 1997 time period. The database covers roughly 1,500 firms per year, including the 500 firms in the S\&P 500 Index, the 400 firms in the S\&P Midcap Index, and the 600 firms in the S\&P Smallcap Index. For up to five top executives from each firm, we retrieve details of their compensation package, including salary, bonus, long-term incentive plan payouts, stock and option

\footnotetext{
${ }^{7}$ Burkart, Gromb, and Panunzi (1997) also simultaneously model both monitoring by outside equityholders and incentive compensation. They show that for some parameter values, monetary incentives and monitoring (through concentrated outside ownership) can coexist in the optimal arrangement.
} 
grants and other compensation reported by the firms in their proxy statements. ${ }^{8}$ The SEC changed proxy disclosure rules in 1992, requiring all firms to disclose stock option grants to their top management. Thus, although option grant data for firms that voluntarily provided it is available in 1992, it is only available for all firms on the database after 1992.

\section{II.A. Measures of Compensation}

We employ several different measures of the structure of managerial compensation. We use the level of pay, where pay is alternatively defined as salary and total direct compensation. The latter consists of the sum of salary, bonus, option and stock grants, long-term incentive plan payouts, and other compensation. In addition, we use two measures of changes in compensation in order to assess pay-for-performance sensitivity. Because salary is virtually fixed and consequently does not possess pay-forperformance sensitivity, we add the bonus to the salary in order to obtain the change in the managers' cash compensation. For a measure of the change if total compensation, we add the other components of compensation, as defined above. ${ }^{9}$ Finally, we employ a measure of particular sensitivity of pay to performance by focusing solely on the options granted to the managers: the sensitivity of option grants to changes in stock price.

None of these measures considers the change in compensation that managers derive from an increase or decrease in the value of the stocks and options they already hold. Whether the consequence of this exclusion is an underestimation of the managers' true pay-for-performance sensitivity depends upon the managers' activities with respect to their personal portfolios. Recent evidence suggests that these activities may be substantial in altering the pay-for-performance sensitivity of managers' current holdings. For example, Ofek and Yermack (2000) report evidence that managers alter

\footnotetext{
${ }^{8}$ The determination of the number of executives is based on the number of executives that the firm lists in their proxy statement. Some firms list less than five.

${ }^{9}$ We use several measures of compensation in the tests because of the differences across them. In particular, total direct compensation is not simply a monotonic increase over salary plus bonus. There is a $55 \%$ correlation between the two measures.
} 
their portfolios in response to the composition of their pay package. Similarly, Bettis, Bizjak and Lemmon (1999) provide evidence that managers counteract the effects of existing holdings through hedging transactions. For their sample of corporate insiders, zero-cost collars and equity swaps cover over a third of the insiders' equity holdings.

Given the difficulty of controlling for managers' activities, using current compensation has the advantage of measuring only the compensation components over which the board of directors has direct control. Our interest is in the influence institutional investors have on executive compensation, rather than an analysis of the optimal managerial ownership dynamics. Since any institutional investor influence, whether direct or indirect, would presumably come through the board's decisions, current compensation measures are more appropriate for our tests. The board has much more limited control (e.g., through vesting and trading restrictions) over the amount of stock and options executives choose to retain in their portfolios, control that may be only partially effective as evidenced by the Ofek and Yermack (2000) and Bettis, Bizjak, and Lemmon (1999) results. The use of current compensation is further justified by the Core and Guay (1998) study in which they differentiate between the stock and flow of CEO equity incentives (options and shares of stocks). They conclude that firms use the flow, i.e., new grants of equity incentives, to reward past performance and to reoptimize incentives for future performance.

\section{II.B. Measures of Institutional Influence}

For every firm on the ExecuComp database, we obtain institutional equity holdings for each year between December 1991 and December 1996 from the CDA Spectrum database. CDA Spectrum derives these holdings from institutional investors' 13-f filings. (Institutional investors with more than $\$ 100$ million in equities must report their equity ownership to the SEC in quarterly 13-f filings). Institutions file their holdings as the aggregate for their firm, regardless of how many individual fund portfolios they have. USAA mutual funds, for example, file one report even though they have over thirty different mutual funds under management. 
We measure institutional investor influence in three ways. We measure total institutional ownership as the fraction of shares outstanding owned by institutions. This measure should primarily capture indirect institutional monitoring, although it may also reflect some direct monitoring. Our second measure of institutional investor influence, the concentration of institutional ownership, is designed to capture the direct institutional monitoring. It is calculated as the proportion of the institutional investor ownership accounted for by the top five institutional investors in the firm.

The third measure of institutional influence is designed to examine whether certain types of institutional investors, such as those that would not be subject to business pressures, are providing monitoring. Specifically, we examine whether investment companies and independent investment advisers are associated with better apparent monitoring.

Besides the data on executive compensation and institutional investor ownership, we also employ further information on each firm in our analyses. Stock returns, stockreturn volatilities and dividend yields are obtained from the Center for Research in Securities Prices (CRSP) and details on assets and liabilities are obtained from Compustat. To be included in the final sample, a firm must have data available from all four sources for a given year. This requirement results in a sample of 36,352 firmexecutive-year observations.

Descriptive statistics on the principal variables of interest are given in Table I. Panel A provides information on firm characteristics and Panel B on institutional holdings. As can be seen from the table, the sample consists of a range of firms with an average market capitalization of $\$ 3.5$ billion, but a median of $\$ 869$ million. The average total direct compensation is $\$ 1.25$ million, where salary plus bonus averages $\$ 525,970$. Reflecting the high stock market returns during the 1990s sample period, the average annual return is $21.8 \%$ and the average annual change in total shareholder wealth is $\$ 571$ million, although there were also firms that performed very poorly. The tenthpercentile return is a negative $23.1 \%$. 
Panel B shows that institutional investors have large interests in the sample firms with average holdings of $53.1 \%$. In fact, the firm at the tenth percentile has institutional holdings of $25.4 \%$, indicating that our sample in general has substantial institutional interest. There is also significant concentration of institutional investors, the average holdings of the top 5 institutional investors in a firm is $22 \%$ of the outstanding shares and $44 \%$ of the institutional holdings. The breakdown of the institutional holdings into the different types of institutions is also shown in Panel B of Table I. The classification into institution type is not precise because institutions report their holdings in aggregate and some institutions span more than one type. For example, banks that own mutual fund companies would combine the trust department and mutual fund holdings into one report. CDA Spectrum classifies an institution by the type that constitutes the majority of their holdings, so these holdings would be reported as a bank if CDA Spectrum estimates that more of its holdings are bank trust assets or an investment company otherwise. For the sample firms, on average, over the time period, $10 \%$ of the shares outstanding are held by bank trust departments, $4.8 \%$ by insurance companies, $9.4 \%$ by investment companies, $24.4 \%$ by independent investment advisers, and $4.5 \%$ by other institutional investors. Because our sample is limited to the 1990s due to the availability of executive compensation data, Panel B shows larger percentage holdings by investment companies and smaller percentage holdings by bank trust departments than do other studies using the CDA database over a longer time frame. Over the last few decades, investment companies and independent investment advisers became relatively more important and bank trust departments became relatively less important.

\section{Relation between institutional investor influence and executive compensation}

In examining the relation between institutional ownership and executive compensation, we need to control for confounding variables. Previous research has found systematic differences in institutional investment across characteristics of the firm such as size (Sias and Starks (1997), Gompers and Metrick (1999)) and performance (Nofsinger and Sias (1999)). Similarly, there is evidence of a relation between managerial 
compensation and these variables. For example, Baker, Jensen and Murphy (1988) document that larger firms (in terms of net sales) have higher paid executives, although Murphy (1998) shows that the explanatory power of firm sales has declined over time. Smith and Watts (1992) have found systematic differences in managerial compensation across size, performance and a firm's growth opportunities (among other variables). They hypothesize that because it is more difficult to observe managers' actions in firms with more growth options, those firms will be more likely to employ incentive plans. Using recent data, Harvey and Shrieves (2000) also document a strong relation between growth opportunities and the presence of incentive compensation.

Given the evidence of systematic differences across firm characteristics in explaining executive compensation and institutional investor ownership, we control for these characteristics in our regressions. We employ several measures of firm size: market capitalization, net sales and total assets. Using Tobin's $q$ ratio, we control for the presence of growth opportunities and to the extent that Tobin's $q$ captures expected performance of the firm, we control for that as well. ${ }^{10}$ We use industry dummy variables to not only control for pay similarities within industries, but also for similarities in institutional investment (these can be thought of as fixed effects at the industry level). Year dummy variables allow both changes in pay and pay-for-performance sensitivity to vary year-by-year. Finally, we employ a CEO dummy variable, equal to one if the executive is the CEO and zero otherwise, to determine if there are differences in the effects qf-pay-for-performance sensitivity for CEOs versus the other top executives of the firm. ${ }^{11}$ One would expect a variation in compensation structure because of the differences in ultimate responsibility for the two groups.

\footnotetext{
${ }^{10}$ Tobin's $q$ is calculated using Compustat data as (the market value of equity less book value of equity plus book value of assets) divided by book value of assets.

${ }_{11}$ In some cases, ExecuComp does not designate which of the executives is the CEO. In this case, we assume the executive with the highest base salary is the CEO.
} 


\section{III.A. Direct institutional investor influence and the level of executive compensation}

The first model we test is the relation between the level of executive compensation and the concentration of institutional ownership:

(1) Level of manager's compensation it $=\beta_{1} \Delta$ (shareholder wealth) $)_{\text {it }}+\beta_{2} \Delta$ (shareholder wealth) $)_{i t-1}+\beta_{3}$ (concentration of top 5 institutions $\left._{\mathrm{it}-1}\right)+\Sigma \beta_{\mathrm{k}}$ (control variables sit $)$,

where the level of compensation is measured by either salary or by total direct compensation (the sum of salary, bonus, option and stock grants, long-term incentive plan payouts, and other compensation), the control variables are Tobin's $q$ ratio, market capitalization, a dummy variable equal to one for each firm's CEO, industry-level dummy variables equal to one for the two-digit SIC in which the firm operates, and year dummies equal to one if the observation is for the given year. We use the concentration of institutional ownership for the prior period in order to control for any changes in institutional ownership that may be related to the year's performance and subsequent higher pay for the executives. Tobin's $q$ ratio, market capitalization, net sales, and total assets are similarly lagged. The results of the regressions are provided in Table II.

The models in Table II show that the level of the top executives' salaries (in Model (1)) and total direct compensation (in Model (2)) are significantly negatively related to institutional ownership concentration. This negative relation is consistent with institutions acting as a check on the level of executive pay. Where ownership is more concentrated, institutions should have an easier time coordinating their efforts and thus more easily exert pressure on management, ensuring that management does not expropriate rents from shareholders in the form of excess compensation. In particular, this result suggests that institutions do monitor managers.

These results hold even after controlling for the firm's growth options and performance (through Tobin's q), the firm's size and industry, the year of the observation, and whether the executive is the CEO or one of the other top executives in 
the firm. ${ }^{12}$ The level of the managerial compensation is also related to the current and previous years' changes in shareholder wealth. As found in previous studies of executive compensation, larger firms pay greater compensation and CEOs receive significantly greater compensation than the rest of the top executive team. The negative relation between level of compensation and Tobin's $q$ suggests that firms with growth opportunities pay less current compensation, possibly because the CEO can expect to receive more in the future due to the expected growth. The coefficients on the CEO dummy indicate that CEOs tend to earn about $\$ 1.5$ million more in total direct compensation than do the other members of the executive team.

To further examine the robustness of our results to our specifications, we estimated the models using only CEOs, rather than the full management team. The results were basically unchanged. ${ }^{13}$ We again found that CEO compensation is decreasing in institutional ownership concentration. In addition, given that institutions tend to invest primarily in the largest firms (Gompers and Metrick (1999)), and given the broad coverage of the ExecuComp database, we used a variety of alternative controls for the size of the firm. Our results are robust to the inclusion of net sales and total assets as additional size proxies, as well as the square of market capitalization as a control for possible nonlinearities in the data. The results are qualitatively very similar if we estimate the regressions using the natural logarithm of compensation (salary or total direct pay) as the dependent variable. (These alternative specifications are not reported for the sake of brevity.)

\section{III.B. Direct institutional investor influence and pay-for-performance sensitivity}

In this section, we examine the relation between direct institutional investor influence and the pay-for-performance sensitivity of executive compensation. We examine this relation using tests based on the following equation:

\footnotetext{
${ }^{12}$ The results are nearly identical whether we employ four-digit or two-digit SIC codes for classifying a firm into an industry.

${ }^{13}$ This specification also potentially benefits the accuracy of the estimated standard errors by using only one observation per firm per year. Thus, our results are not being driven by incorrect standard errors due to correlation within a given firm-year.
} 


$$
\begin{aligned}
& \left.\Delta \text { (manager's compensation })_{\text {it }}=\beta_{1} \Delta \text { (shareholder wealth }\right)_{\text {it }-1} \\
& +\Delta \text { (shareholder wealth })_{\text {it }}{ }^{*}\left[\beta_{2}(\% \text { owned by institutions } \text { it- } 1)+\right. \\
& \left.\left.\left.\beta_{3} \text { (concentration of top } 5 \text { institutions }_{\mathrm{it}-1}\right)+\Sigma \beta_{\mathrm{k}} \text { ( } \text { control variables }_{\mathrm{it}}\right)\right]+ \\
& \Sigma \beta_{\text {y }} \text { year dummy variables }{ }_{t} \text {, }
\end{aligned}
$$

where the managerial compensation is measured by either salary plus bonus or by total direct compensation (the sum of salary, bonus, option and stock grants, long-term incentive plan payouts, and other compensation) and the control variables are Tobin's $q$ ratio, market capitalization, net sales, total assets, a dummy variable equal to one for each firm's CEO, industry-level dummy variables equal to one for the two-digit SIC in which the firm operates, and year dummies equal to one if the observation was for the given year. ${ }^{14}$ We have also included a variable to measure indirect institutional influence, the aggregate ownership of institutions. We discuss the results on this variable in the next section.

The first two columns of Table III provide the regression results when the manager's compensation is defined as salary plus bonus. The two models use different specifications to control for size effects. In the first model, market capitalization is employed alone. In the second model, because the relevant size variable to control for differences in compensation is not clear, we include all three size control variables: market capitalization, net sales and total assets.

The results in Table III show that regardless of the specification for size, the concentration of institutional ownership is significantly positively related to a firm's payfor-performance sensitivity. As the regression results show, pay-for-performance sensitivity is affected by institutional ownership concentration, even after controlling for growth opportunities, size, industry fixed effects, and whether the executive is CEO. The more concentrated is institutional ownership, the greater the pay-for-performance sensitivity of top management's salary and bonus compensation. These results are

\footnotetext{
${ }^{14}$ The year dummies enter the regression twice: once as intercept terms, and once interacted with the change in shareholder wealth. Thus, they control for time-specific variation in both changes in pay, and changes in pay-for-performance sensitivity. Hall and Liebman (1998) show that pay-for-performance sensitivity has increased since the 1980s.
} 
consistent with Black's (1992) argument that institutions should take on a stronger monitoring role by holding larger stakes in companies and teaming up with other institutional investors to have more influence. The hypothesis of greater institutional monitoring leading to better CEO compensation structures is also consistent with the results of research that finds a relation between CEO compensation and the firm's board or ownership structure. For example, Core, Holthausen and Larcker (1999) find that cross-sectional variation in CEO compensation can be partially explained by measures of board and ownership structure.

The regressions also show that pay-for-performance sensitivity is stronger for the CEO than for the other top managers of the firm. Pay-for-performance sensitivity is negatively related to size, consistent with previous studies that have found smaller firms pay more incentive pay than do larger firms (e.g., Murphy (1998)).

Columns three, four, and five of Table III expand the definition of managerial compensation to include other forms of compensation besides the cash compensation from salary and bonus payments. The measure also includes stock and option grants for the year, long-term incentive compensation and any other compensation. Model (3) provides the results using only market capitalization as the control for size. Model (4) shows that the results are basically invariant when other measures for firm size are included as well. ${ }^{15}$ Finally, Model (5) controls for firm-level fixed effects and again shows that the results are comparable no matter which specification is employed. The consistency in results across Models (4) and (5) implies that our results are not driven by cross-sectional variation across firms alone, or by unobservable firm-specific variables. Even within a given firm, ownership concentration is positively related to pay-forperformance sensitivity. Put another way, our findings are not being driven by certain "types" of firms (subject to firm types remaining constant over our sample period).

When we expand the measure of compensation to total direct compensation, we once again find that the pay-for-performance sensitivity is positively related to

\footnotetext{
${ }^{15}$ As with the results for the level of pay, our results for pay-for-performance sensitivity are robust to various controls for a nonlinear size effect, such as the inclusion of the square of market capitalization as a determinant of sensitivity.
} 
institutional ownership concentration. The result that performance sensitivity of the executive compensation is significantly positively related to institutional ownership concentration is consistent with the hypothesis that institutional influence is a complementary monitoring mechanism to incentive compensation. This result is consistent with the Chidambaran and John (1999) theoretical argument on the complementarity of institutional investor ownership and managerial compensation. Furthermore, the significantly positive coefficient on the concentration of institutional ownership variable suggests that institutional investors have a direct monitoring effect as reported in the anecdotal press accounts and Useem (1996).

While economic significance is certainly in the eye of the beholder, the effects of institutional investor influence are relatively large compared to the average pay-forperformance sensitivity in our sample. While CEOs' pay-for-performance sensitivity of salary plus bonus averages $\$ 0.032$ per $\$ 1,000$ change in shareholder wealth, the estimates from Model (2) imply that a one-standard-deviation increase in institutional ownership concentration is associated with a $\$ 0.005$ increase in sensitivity, an increase of $16 \%$. Similarly, CEOs' pay-for-performance sensitivity of total direct compensation averages $\$ 0.18$ per $\$ 1,000$ change in shareholder wealth, and a one-standard-deviation increase in institutional ownership concentration implies a $\$ 0.040$ increase in sensitivity (using Model (4)).

\section{III.C. Indirect institutional investor influence and pay-for-performance sensitivity} As discussed previously, the institutional investor monitoring may also result indirectly from the institutions' preferences and trading. We measure the indirect influence by the total percentage institutional ownership. As shown in Table III, regardless of the model specification, pay-for-performance sensitivity is positively related to the level of total institutional ownership. In terms of economic significance, the estimates from Model 4 imply that a one standard deviation increase in total institutional ownership is associated with a $\$ 0.037$ increase in pay-for-performance sensitivity, an increase in sensitivity of $22 \%$. 
While this is of comparable magnitude to the effect of concentration, it should be noted that our proxy for the indirect effect, the total percentage institutional ownership, might be partially measuring the direct influence. A large institutional presence (in levels but not concentration) could also be associated with increased direct pressure on the firm. Thus, one can think of this measure as an upper bound on the magnitude of the indirect effect. We use total ownership as our proxy for the indirect effect because actions taken by firms to attract institutions should affect the total ownership, but not its concentration. In fact, if we test for this possibility by regressing the change in ownership concentration on time $t-1$ pay-for-performance sensitivity, we find no significant relation (results not reported). ${ }^{16}$

\section{III.D. Institutional investor influence and option-grant sensitivity}

Stock-option grants have become an increasingly important component of executive pay. In fact, Murphy (1998) states that in the 1990s, stock options have replaced base salaries as the single largest component of compensation. Because a firm's option grants are a particular form of specific pay-for-performance, we analyze the option-grant pay-for-performance sensitivity separately from that of other types of compensation. Analyzing the option grants independently is also important because of the increasing interest by institutional investors in firms' option compensation. Another advantage of this approach is that it uses an ex ante measure of pay sensitivity compared to the ex post nature of the regressions above. Option-grant sensitivity can be directly calculated using observed option-grant data and is not subject to the noise inherent in using slope coefficients as sensitivity estimates.

We conduct a Tobit analysis of the pay-for-performance sensitivity of option grants as a function of institutional investor ownership because many firms still do not pay their managers with stock options and even those firms that do use options, do not necessarily grant them every year. To calculate the option-grant sensitivity, we use the

\footnotetext{
${ }^{16}$ For this reverse regression, we use option-grant sensitivity as the independent variable because our other measure of sensitivity is estimated using slope coefficients, and not directly observable.
} 
methodology suggested by Yermack (1995). First, we calculate the delta of each option grant, $\partial \mathrm{C} / \partial \mathrm{P}$ (where $\mathrm{C}$ is the value of the call option and $\mathrm{P}$ is the price of the stock), by using the Black-Scholes model modified for dividends. We derive dividend yields and volatilities from the CRSP data. We then multiply the delta of each option grant by the number of options granted and divide by the number of shares outstanding at the beginning of the year. Since this number is the sensitivity of the option grant per dollar change in share value, we then multiply it by 1,000, which gives the familiar dollar change in managerial wealth per $\$ 1,000$ change in shareholder wealth. For years in which executives receive multiple option grants, the sensitivities are aggregated across each year for each manager. We find that the average option-grant sensitivity for this sample is $\$ 0.9665$ per $\$ 1,000$ change in shareholder wealth, with a median of $\$ 0.1711$ and a standard deviation of $\$ 3.144$. While these are much higher than Yermack's mean and median of $\$ 0.59$ and $\$ 0.07$, the difference is consistent with the increasing role of options in compensation over the $1990 \mathrm{~s}^{17}$

The option-grant sensitivity is the dependent variable in the Tobit regressions whose results are shown in Table IV. Consistent with Table III, we find that both the total percentage holdings of institutional investors and the concentration of the top five institutions are important in explaining option-grant pay-for-performance sensitivity. These results further suggest that institutional investors are a complimentary monitoring device and the positive coefficient on the concentration variable implies that the institutions provide a direct influence on the structure of executive compensation.

Table IV additionally shows that the option grant pay-for-performance sensitivity is positively related to Tobin's $q$ ratio and highly significant. This result is consistent with the hypothesis and evidence of Smith and Watts (1992) regarding firms with greater growth opportunities. They argue that such firms should have more incentive pay and in support of this argument they find that industries with higher average Tobin's $q$ ratios have greater proportions of firms with option plans. However, inconsistent with our

\footnotetext{
${ }^{17}$ Yermack's sample ends in 1991.
} 
results and those of Smith and Watts (1992), Yermack (1995) finds a significantly negative relation between CEO option-grant sensitivity and Tobin's $q$ ratio.

One concern about our results is the possibility that recent increasing trends for both institutional ownership and option compensation are driving the results. To examine this possibility, we conducted two additional tests. First, we ran a regression to see if lagged sensitivity of option grants would predict subsequent institutional ownership. The results were insignificant. Second, we repeated our analysis in Table IV on a per-year basis (results not reported). For four out of the five annual cross-sectional regressions, we find that the pay-for-performance sensitivity of the option grants is related to the level of institutional ownership and the concentration of that ownership, indicating that our results are not driven by common trends. These results are also consistent with the hypothesis that the institutional influence is direct rather than indirect. In addition, we estimated a random effects panel Tobit model (with effects at the firm level) to check the robustness of the model specification. There was no substantial change in results. Thus, as in Table $\|$ our results in Table IV do not appear to be driven by unobservable firm heterogeneity. ${ }^{18}$

\section{III.E. Type of institutional investor and institutional investor influence}

Institutional investors vary in terms of their incentives, regulatory and competitive environments and clienteles. All of these factors may affect the degree to which a given institution will purchase and monitor a corporation. ${ }^{19}$ As already noted, Brickley, Lease and Smith (1988) point out differences in the pressure-sensitivity of institutional shareholders due to business relations with the company. Murphy and Van Nuys (1994) discuss the conflicting incentives for activist public institutions. Because some types of

\footnotetext{
${ }^{18}$ We employed random effects here rather than fixed effects due to the use of maximum likelihood in estimating the model.

${ }^{19}$ See Del Guercio (1996), Falkenstein (1996), and Bennett, Sias and Starks (2000) for research on the relation between type of institutional investor and the institutions' preferences for certain stock characteristics. See Almazan, Brown, Carlson, and Chapman (2000) for research on the effects of constraints on portfolio manager decisions.
} 
institutions are more likely to use their influence than other types, in this section we examine the institutional ownership concentration by type of institution.

Following the Brickley, Lease and Smith (1988) definition of which institutions would be pressure-insensitive, we separate out these institutions from our institutional concentration variable. The pressure-insensitive concentration measure is then the sum of the shares owned by the top- 5 institutions that are either investment companies or independent investment advisers. The other institutions (insurance companies, banks and other) are then included in the pressure-sensitive concentration measure.

To determine whether certain types of institutional investors appear to have more influence than do others, as in equation (1), we regress the level of compensation on these two separate measures of institutional concentration. The results of this regression are provided in Table $\mathrm{V}$. Compensation is measured by salary in Model (1) and by total direct compensation in Model (2).

Increased concentration by both pressure-sensitive and pressure-insensitive institutional investors is associated with lower levels of salary and total direct compensation. Further, a Wald F-statistic rejects the null hypothesis of equality for the coefficients of the two types of institutional investors, showing that the pressureinsensitive institutional investor concentration is more negatively associated with salary.

In Table VI, we repeat the analyses of Table III (the relation between pay-forperformance sensitivity and institutional influence), where once again, we substitute the pressure-sensitive and pressure-insensitive concentration measures for the previously aggregated concentration measure. Model (1) shows the relation using salary plus bonus and Model (2) shows the relation using total direct compensation. In both cases, we find substantial variation in the relation between the pay-for-performance sensitivity of the executives' compensation and institutional concentration across the different types of institutions. For the pay-for-performance sensitivity of salary plus bonus and total direct compensation, the pressure-insensitive institutional concentration has a significant positive relation, while the pressure-sensitive institutional concentration has no 
significant relation. These results suggest that some types of institutions have a stronger association with incentive compensation. ${ }^{20}$

The results of Tables $\mathrm{V}$ and $\mathrm{VI}$ imply that investment companies and independent investment advisers play more of a monitoring role than do other types of institutions. They are consistent with the Brickley, Lease and Smith (1988) hypothesis that these institutions are more pressure-insensitive than other types. That is, because investment companies and independent investment advisers in general are less likely to be concerned about their future business relations with a given firm, they are more likely to put pressure on that firm to mitigate shareholder-manager agency conflicts. Thus, those firms are likely to have less excessive compensation and more incentive compensation.

\section{Conclusions}

We find a strong relation between a firm's executive compensation structure and its institutional influence. We find that the level of managerial compensation is negatively related to the concentration of that ownership, suggesting that institutional investors serve a direct monitoring role in mitigating shareholder-manager agency conflicts. Using various measures of pay-for-performance sensitivity, we find that the performancesensitivity of the executive compensation is positively related to aggregate institutional ownership and the concentration of that ownership. These results imply that the presence of institutional investors as owners is related to the adoption of compensation schedules with more pay-for-performance sensitivity, suggesting that institutional investors contribute to corporate governance of the firm, both directly through their intervention and indirectly through their preferences. Given the strong positive relation between institutional influence and pay-for-performance sensitivity, we conclude that the institutional influence is a complementary monitoring mechanism to incentive compensation in mitigating the shareholder-manager agency problem.

\footnotetext{
${ }^{20}$ We find the same differences between the two types of institutional investors when we use the option-grant sensitivity.
} 
Furthermore, we find that institutions which are less likely to be sensitive to pressure from management have the strongest association with executive pay. Our results are consistent whether we use ex post measures of pay-for-performance sensitivity, such as slope estimates from regressions, or ex ante measures, such as option-grant sensitivity. 


\section{References}

Allen, Franklin, Antonio Bernardo, and Ivo Welch, 2000, A Theory of Dividends Based on Tax Clienteles, Journal of Finance, forthcoming.

Allen, Franklin, and Andrew Winton, 1995, Corporate Financial Structure, Incentives and Optimal Contracting, in Handbooks in Operations Research and Management Science, 9: Finance, R. A. Jarrow, V. Maksimovic, and W. T. Ziemba (editors), Elsevier Science Ltd.

Almazan, Andres, Keith Brown, Murray Carlson, and David Chapman, 2000, Why Constrain Your Mutual Fund Manager? University of Texas at Austin working paper

Baker, George, Michael Jensen, and Kevin Murphy, 1988, Compensation and Incentives: Practice vs. Theory, Journal of Finance 43, 593-616.

Bennett, James, Richard Sias, and Laura T. Starks, 2000, Stock Characteristics and Institutional Preferences: Differences Across Type and Time, University of Massachusetts, Washington State University and University of Texas working paper.

Bettis, J. Carr, John Bizjak, and Michael Lemmon, 1999, Insider Trading in Derivative Securities: An Empirical Examination of the Use of Zero-Cost Collars and Equity Swaps by Corporate Insiders, Arizona State University and Portland State University working paper.

Bhide, A., 1994, Efficient markets, Deficient Governance: U.S. Securities Regulations Protect Investors and Enhance Market Liquidity. But Do They Alienate Managers and Shareholders? Harvard Business Review 72, 128-140.

Black, Bernard, 1992, Agents Watching Agents: The Promise of Institutional Investor Voice, UCLA Law Review 39, 811-893.

Borokhovich, Kenneth, Kelly Brunarski, and Robert Parrino, 2000, Variation in the Monitoring Incentives of Outside Blockholders, Cleveland State University, Miami University, and University of Texas working paper.

Brickley, James, Ronald Lease, and Clifford Smith, 1988, Ownership Structure and Voting on Antitakeover Amendments, Journal of Financial Economics 20, 267-292.

Brown, Keith, and Bryce Brooke, 1993, Institutional Demand and Security Price Pressure, Financial Analysts Journal, 53-63.

Burkart, Mike, Denis Gromb, and Fausto Panunzi, 1997, Large Shareholders, Monitoring, and the Value of the Firm, Quarterly Journal of Economics 112, 693728.

Bushee, Brian, 1998, The Influence of Institutional Investors on Myopic R\&D Investment Behavior, The Accounting Review 73, 305-333.

Bushee, Brian, and Christopher Noe, 1999, Unintended Consequences of Attracting Institutional Investors with Improved Disclosure, Harvard University working paper.

Carpenter, Jennifer, 1999, Does Option Compensation Increase Managerial Risk Appetite? Journal of Finance, forthcoming. 
Chidambaran, Nemmara, and Kose John, 1999, Relationship Investing, Managerial Compensation, and Corporate Governance, Tulane University and New York University working paper.

Coffee, John, 1991, Liquidity versus Control: The Institutional Investor as Corporate Monitor, Columbia Law Review 91, 1277-1368.

Colvin, G., 1992, How to Pay the CEO Right, Fortune (April 6), p. 60.

Core, John, and Wayne Guay, 1998, The Stock and Flow of CEO Equity Incentives, University of Pennsylvania working paper.

Core, John, Robert Holthausen, and David Larcker, 1999, Corporate Governance, Chief Executive Officer Compensation, and Firm Performance, Journal of Financial Economics 51, 371-406.

Del Guercio, Diane, 1996, The Distorting Effects of the Prudent-Man Laws on Institutional Equity Investments, Journal of Financial Economics 40, 31-62.

Falkenstein, Erik, 1996, Preferences for Stock Characteristics as Revealed by Mutual Fund Holdings, Journal of Finance 51, 111-136.

Fama, Eugene F., and Michael C. Jensen, 1983, Separation of ownership and control, Journal of Law and Economics 26, 301-325.

Gibbons, Michael, and Kevin Murphy, 1990, Relative Performance Evaluation for Chief Executive Officers, Industrial and Labor Relations Review 43, 30-51.

Gillan, Stuart, and Laura Starks, 2000, Corporate Governance Proposals and Shareholder Activism: The Role of Institutional Investors, Journal of Financial Economics, forthcoming.

Gillan, Stuart, and Laura Starks, 1998, A Survey of Shareholder Activism: Motivation and Empirical Evidence, Contemporary Finance Digest.

Gompers, Paul, and Andrew Metrick, 1999, Institutional Investors and Equity Prices, Quarterly Journal of Economics, forthcoming.

Gorton, Gary, and Matthias Kahl, 1999, Blockholder Identity, Equity Ownership Structures and Hostile Takeovers, NBER working paper, Number 7123.

Grossman, Sanford, and Oliver Hart, 1980, Takeover Bids, the Free Rider Problem, and the Theory of the Corporation, Bell Journal of Economics 11, 42-64.

Guay, Wayne, 1999, The Sensitivity of CEO Wealth to Equity Risk: An Analysis of the Magnitude and Determinants, Journal of Financial Economics 53, 43-71.

Hall, Brian J., and Jeffrey B. Liebman, 1998, Are CEOs Really Paid Like Bureaucrats? Quarterly Journal of Economics 113, 653-691.

Hartzell, Jay, 1999, The Impact of the Likelihood of Turnover on Executive Compensation, New York University working paper.

Harvey, Keith D., and Ronald E. Shrieves, 2000, Executive Compensation Structure and Corporate Governance Choices, Boise State University and University of Tennessee working paper.

Holmstrom, Bengt, 1979, Moral Hazard and Observability, Bell Journal of Economics 10, 74-91. 
Holmstrom, Bengt, 1982, Moral Hazard in Teams, Bell Journal of Economics 13, 324340.

Holmstrom, Bengt, and Jean Tirole, 1993, Market Liquidity and Performance Monitoring, Journal of Political Economy 101, 678-709.

Hotchkiss, Edith, and Deon Strickland, 2000, Does Shareholder Composition Affect Stock Returns? Evidence from Corporate Earnings Announcements, Boston College and Ohio State University working paper.

Huddart, Steven, 1993, The Effect of a Large Shareholder on Corporate Value, Management Science 39, 1407-1421.

Jensen, Michael, 1983, The Modern Industrial Revolution, Exit, and the Failure of Internal Control Systems, Journal of Finance 48, 831-880.

Jensen, Michael, and Kevin Murphy, 1990, Performance Pay and Top-Management Incentives, Journal of Political Economy 98, 225-264.

John, Teresa, and Kose John, 1993, Top Management Compensation and Capital Structure, Journal of Finance 48, 949-74.

Johnson, Marilyn, and Margaret Shackell, 1997, Shareholder Proposals on Executive Compensation, University of Michigan working paper.

Johnson, Marilyn, Sue Porter, and Margaret Shackell, 1997, Stakeholder Pressure and the Structure of Executive Compensation, University of Michigan working paper.

Kahn, Charles, and Andrew Winton, 1998, Ownership Structure, Speculation, and Shareholder Intervention, Journal of Finance 53, 99-129.

Maug, Ernst, 1998, Large Shareholders as Monitors: Is There a Trade-off between Liquidity and Control? Journal of Finance 53, 65-98.

Maxey, D., and R. ten Wolde, 1998, CEO Pay May be Crucial as Funds Shop, Wall Street Journal May 26, C25.

Mikkelson, Wayne, and M. Megan Partch, 1997, The Decline of Takeovers and Disciplinary Managerial Turnover, Journal of Financial Economics 44, 205-228.

Murphy, Kevin, 1985, Corporate Performance and Managerial Remuneration: An Empirical Analysis, Journal of Accounting and Economics 7, 11-42.

Murphy, Kevin, 1998, Executive Compensation, in Handbook of Labor Economics, Ashenfelter, O., and Card, D. (editors), Volume 3, North Holland.

Murphy, Kevin, and Karen Van Nuys, 1994, State Pension Funds and Shareholder Inactivism, Harvard University working paper.

Noe, Thomas, 1998, Institutional Activism and Financial Market Structure, Tulane University working paper.

Nofsinger, John, and Richard Sias, 1999, Herding and Feedback Trading by Institutional and Individual Investors, Journal of Finance 54, 2263-2295

Ofek, Eli, and David Yermack, 2000, Taking Stock: Equity-Based Compensation and the Evolution of Managerial Ownership, Journal of Finance, forthcoming.

Parrino, Robert, Richard W. Sias, and Laura T. Starks, 2000, Voting With Their Feet: Institutional Investors and CEO Turnover, University of Texas working paper. 
Pound, John, 1992, Beyond Takeovers: Politics Comes to Corporate Control, Harvard Business Review 70.

Pulliam, S., 1993, Big Investors, Even Money Managers, Join Activists' Ranks for Better Bottom Lines, The Wall Street Journal (Feb. 5), p. C1.

Ross, Stephen, 1999, Some Notes on Compensation, Agency Theory, and the Duality of Risk Aversion and Riskiness, MIT working paper.

Shavell, Steven, 1979, Risk Sharing and Incentives in the Principal and Agent Relationship, Bell Journal of Economics 10, 55-73.

Shleifer, Andrei, and Robert Vishny, 1986, Large Shareholders and Corporate Control, Journal of Political Economy 94, 461-48.

Sias, Richard, and Laura T. Starks, 1997, Institutions and Individuals at the Turn-of-theYear, Journal of Finance 52, 1543-1562.

Sias, Richard, Laura T. Starks, and Sheridan Titman, 2000, The Price Impact of Institutional Trading, Washington State University and University of Texas at Austin working paper.

Smith, Michael, 1996, Shareholder Activism by Institutional Investors: Evidence from CalPERS, Journal of Finance 51, 227-252.

Smith, Clifford, and Rene Stulz, 1985, The Determinants of Firm's Hedging Policies, Journal of Financial and Quantitative Analysis 20, 391-405.

Smith, Clifford, and Ross Watts, 1992, The Investment Opportunity Set and Corporate Financing, Dividend, and Financing Policies, Journal of Financial Economics 32, 262-292.

Useem, Michael, 1996, Investor Capitalism: How Money Managers are Changing the Face of Corporate America (New York: Basic Books).

Wahal, Sunil, and John J. McConnell, 1999, Do institutional investors exacerbate managerial myopia? Emory University and Purdue University working paper.

Yermack, David, 1995, Do Corporations Award CEO Stock Options Effectively? Journal of Financial Economics 39, 237-269. 


\section{Table I}

\section{Summary Statistics}

This table shows the sample statistics for the principal variables. Panel A shows the firm characteristics over the 1992-1997 time period and Panel B shows the institutional investor holdings over the 19911996 time period (in the empirical tests, institutional holdings are lagged by one year). Market capitalization is the number of shares outstanding times the price at the beginning of the year. Cash compensation is the manager's salary plus bonus for the year. Total direct compensation is the sum of the manager's salary, bonus, stock and option grants, and other compensation. $\Delta\left(\right.$ Shareholder wealth $\left._{\mathrm{t}}\right)$ is defined as the change in value of the shares outstanding times stock price from period $t-1$ to period $t$. Institutional holdings are calculated as the shares held by institutional investors who file 13-f reports divided by the total number of shares outstanding except for the variable that shows the top 5 institutional holdings as a percentage of total institutional holdings.

\begin{tabular}{|c|c|c|c|c|c|}
\hline \multicolumn{6}{|l|}{ Panel A. Firm Characteristics } \\
\hline Variable & Mean & Median & $\begin{array}{l}\text { Standard } \\
\text { Deviation }\end{array}$ & $10 \%$ & $90 \%$ \\
\hline Market capitalization ( $\$ M M)$ & $3,476.93$ & 869.91 & $9,477.30$ & 155.78 & $7,469.07$ \\
\hline Cash compensation (Salary + bonus, $\$ K$ ) & 525.97 & 361.85 & 813.66 & 155.17 & $1,000.00$ \\
\hline Total direct compensation $(\$ \mathrm{~K})$ & $1,250.16$ & 645.03 & $2,910.64$ & 215.97 & $2,540.77$ \\
\hline Return & $21.8 \%$ & $15.7 \%$ & $49.3 \%$ & $-23.1 \%$ & $69.2 \%$ \\
\hline$\Delta($ Shareholder wealth $)(\$ \mathrm{MM})$ & 570.74 & 99.11 & $2,762.85$ & -186.32 & $1,363.37$ \\
\hline \multicolumn{6}{|l|}{ Panel B. Institutional Investor Holdings } \\
\hline Variable & Mean & Median & $\begin{array}{l}\text { Standard } \\
\text { Deviation }\end{array}$ & $10 \%$ & $90 \%$ \\
\hline \multicolumn{6}{|l|}{ Holdings as a \% of shares outstanding: } \\
\hline Total institutional holdings & $53.1 \%$ & $54.8 \%$ & $19.4 \%$ & $25.4 \%$ & $77.3 \%$ \\
\hline Holdings of top 5 institutions & 22.3 & 21.5 & 9.7 & 10.6 & 34.3 \\
\hline $\begin{array}{l}\text { Holdings of top } 5 \text { institutions } \\
\text { (as \% of institutional holdings) }\end{array}$ & 44.0 & 42.1 & 14.6 & 26.5 & 64.4 \\
\hline Bank trust departments & 10.0 & 8.7 & 6.7 & 2.9 & 18.5 \\
\hline Insurance companies & 4.8 & 3.9 & 4.3 & .9 & 9.2 \\
\hline Investment companies & 9.4 & 7.7 & 7.5 & 1.4 & 19.8 \\
\hline Independent investment advisers & 24.4 & 23.5 & 11.9 & 9.4 & 40.6 \\
\hline Other institutional investors & 4.5 & 3.7 & 4.4 & .6 & 9.0 \\
\hline
\end{tabular}




\section{Table II}

\section{Level of Executive Compensation as a Function of Institutional Influence}

Dependent variables: Salary or Total Direct Compensation

This table shows the coefficients from a regression of the manager's compensation against the change and lagged change in shareholder's wealth, holdings of top 5 institutions as a percent of institutional holdings and controls for firm size (Market capitalization, net sales, total assets) and Tobin's $q$ ratio. Further control variables are a CEO dummy that equals one if the executive is CEO and 0 otherwise and a series of control dummies for the firm's two-digit SIC industry and for time. (The coefficients for the latter variables are not shown in the table.) T-statistics are provided in parentheses. One, two, and three asterisks denote significance at the $0.10,0.05$, and 0.01 levels, respectively.

Dependent variable:

$\underline{\text { Independent Variable }}$

$\Delta(\text { Shareholder wealth })_{\mathrm{t}}$

$\Delta\left(\right.$ Shareholder wealth $\left.\mathrm{t}_{\mathrm{t}-1}\right)$

Top 5 /Total Institutional Ownership $\mathrm{t}_{\mathrm{t}-1}$

Tobin's $q_{\mathrm{t}-1}$

Market Capitalization $_{\mathrm{t}-1}$

CEO Dummy

Number of observations

Adjusted $\mathrm{R}^{2}$
Total Direct

Salary $_{t}$

0.001

$-0.005^{\star \star \star}$ $(-10.30)$

$-304.441^{* * *}$

$(-48.99)$

$-20.430^{* * *}$

$(-29.28)$

$0.008^{* * *}$

(47.12)

$268.190^{\text {** }}$

(126.60)

36,346

0.45
Compensation $_{t}$

(2)

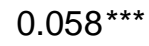

(10.14)

$0.040^{\text {*** }}$

$-2,189.257^{* * *}$

$(-22.64)$

$-58.163^{\text {*** }}$

$0.045^{\star * *}$

$1,500.970^{* * *}$

(46.62)

33,278

0.18 


\section{Table III}

\section{Pay-for-Performance Sensitivity as a Function of Institutional Influence}

\section{Dependent variables: $\Delta$ (Salary Plus Bonus) or $\Delta$ (Total Direct Compensation)}

This table shows the coefficients from a regression of the change in the manager's compensation against the lagged change in shareholder's wealth and the change in shareholder's wealth interacted with percentage holdings of institutions filing 13-f reports, holdings of top 5 institutions as a percent of institutional holdings and controls for firm size (Market capitalization, net sales, total assets) and Tobin's $q$ ratio. Further control variables are a CEO dummy that equals one if the executive is CEO and 0 otherwise and a series of control dummies for the firm's two-digit SIC industry and for time. (The coefficients for the latter variables are not shown in the table.) Models (1) and (2) have $\Delta$ (Salary plus bonus) as the dependent variable and Models (3) (4), and (5) have $\Delta$ (Total Direct Compensation) as the dependent variable. Model (5) is with firm fixed effects. T-statistics are provided in parentheses. One, two, and three asterisks denote significance at the $0.10,0.05$, and 0.01 levels, respectively.

Dependent variable:

$\Delta($ Salary + Bonus $)$

\section{$\underline{\text { Independent Variable }}$}

$\Delta\left(\right.$ Shareholder wealth $\left.\mathrm{t}_{\mathrm{t}-1}\right)$

$\Delta($ Shareholder wealth $) X$

Total Institutional Ownership $\mathrm{t}_{\mathrm{t}-1}$

Top 5 /Total Instl. Ownership t-1 $_{1}$

Tobin's $q_{\mathrm{t}-1}$

Market Capitalization $_{\mathrm{t}-1}$

Net Sales $\mathrm{t}_{-1}$

Total Assets $\mathrm{t}_{-1}$

CEO Dummy

Number of observations

Adjusted $\mathrm{R}^{2}$
(1)

$\begin{array}{ll}0.001 & 0.001 \\ (0.51) & (0.52) \\ & \\ 0.050^{\star \star *} & 0.065^{\star * *} \\ (4.00) & (4.86) \\ 0.035^{\star *} & 0.036^{\star *} \\ (2.18) & (2.18) \\ -0.003^{\star * *} & -0.004^{\star * *} \\ (-3.84) & (-3.87) \\ -0.172^{\star * *} & -0.087 \\ (-4.14) & (-1.22) \\ & 0.213^{* * *} \\ & (2.04) \\ & -0.118^{* *} \\ 0.023^{* * *} & (3.21) \\ (8.12) & 0.023^{* * *} \\ & (8.10)\end{array}$

36,346

0.01

.04)

$(3.21)$

(8.10)

36,307

0.01

$\Delta\left(\right.$ Total Direct Compensation $\left._{\mathrm{t}}\right)$

(3)

$0.091^{\text {** }}$
$(9.02)$

$0.095^{*}$

(1.72)

$0.246^{* \star}$

(3.41)

$-0.002$

$(-0.51)$

$-1.387^{* *}$

$(-7.54)$

27,612

0.03
(4)

(5)

\begin{tabular}{|c|c|}
\hline $\begin{array}{l}0.094^{* * *} \\
(9.24)\end{array}$ & $\begin{array}{l}0.079^{* \star *} \\
(6.14)\end{array}$ \\
\hline $0.193^{* * *}$ & $0.404^{* * *}$ \\
\hline (3.27) & $(4.72)$ \\
\hline $0.273^{* * *}$ & $0.243^{* *}$ \\
\hline (3.71) & $(2.48)$ \\
\hline-0.001 & 0.008 \\
\hline$(-0.24)$ & (1.63) \\
\hline$-1.392^{* \star *}$ & -0.781 \\
\hline$(-4.50)$ & $(-2.97)^{\star \star \star}$ \\
\hline $0.002^{* * *}$ & \\
\hline$(4.49)$ & \\
\hline$-0.001^{* * *}$ & \\
\hline$(-3.83)$ & \\
\hline $0.084^{* * *}$ & $0.085^{\star * *}$ \\
\hline$(7.42)$ & $(7.45)$ \\
\hline
\end{tabular}

$\begin{array}{lll}(7.42) & (7.42) & (7.45)\end{array}$
27,612

0.03 


\section{Table IV}

Tobit Analysis of Pay-for-Performance Sensitivity of Option Grants as a Function of Institutional Ownership

Dependent variable: $\Delta$ in Value of Options Granted per $\$ 1,000 \Delta$ in Shareholder Wealth

This table shows the coefficients from a regression of the change in the value of options granted a manager per a $\$ 1000$ change in shareholder wealth against the lagged change and change in shareholder's wealth, and percentage holdings of institutions filing 13-f reports (in total and divided by type of institution), holdings of top 5 institutions as a percent of institutional holdings and controls for firm size (Market capitalization, net sales, total assets) and Tobin's $q$ ratio. Further control variables are a CEO dummy that equals one if the executive is CEO and 0 otherwise and a series of control dummies for the firm's two-digit SIC industry and for time. (The coefficients for the latter variables are not shown in the table.) T-statistics are provided in parentheses. One, two, and three asterisks denote significance at the 0.10, 0.05, and 0.01 levels, respectively.

$\underline{\text { Independent Variable }}$

$\Delta(\text { Shareholder wealth })_{\mathrm{t}}$

$\Delta\left(\right.$ Shareholder wealth $\left.h_{\mathrm{t}-1}\right)$

Total Institutional Ownership $\mathrm{t}_{\mathrm{-}-1}$

Top 5 /Total Institutional Ownership $\mathrm{t}_{\mathrm{t}-1}$

Tobin's $q_{\mathrm{t}-1}$

Market Capitalization $_{\mathrm{t}-1}$

Net Sales t-1 $_{1}$

Total Assets $_{\mathrm{t}-1}$

CEO Dummy

Number of observations
(1)

7.450

(0.85)

0.611

$0.822^{\text {*** }}$

(6.59)

$1.338^{* * *}$

$0.066^{* * *}$

$-10.400^{* * *}$

$(-2.53)$

6.810

(0.77)

3.520

$(0.27)$

$0.798^{* \star *}$

$1.357^{* \star *}$

$0.072^{* * *}$

$-15.900^{* * *}$

3.090

(0.79)

2.152

(1.64)

$1.388^{* * *}$

(28.54)

$1.385^{* * *}$

(28.48)

33,398

33,364 


\section{Table V \\ Level of Executive Compensation as a Function of Institutional Influence Divided by Type of Institution}

Dependent variables: Salary or Total Direct Compensation

This table shows the coefficients from a regression of the manager's compensation against the change and lagged change in shareholder's wealth, holdings of top 5 institutions as a percent of institutional holdings (divided by type of institution) and controls for firm size (Market capitalization, net sales, total assets) and Tobin's $q$ ratio. Further control variables are a CEO dummy that equals one if the executive is CEO and 0 otherwise and a series of control dummies for the firm's two-digit SIC industry and for time. (The coefficients for the latter variables are not shown in the table.) Tstatistics are provided in parentheses. One, two, and three asterisks denote significance at the 0.10 , 0.05 , and 0.01 levels, respectively.

Dependent variable:

Independent Variable

$\Delta\left(\right.$ Shareholder wealth $\left.{ }_{\mathrm{t}}\right)$

$\Delta\left(\right.$ Shareholder wealth $\left.\mathrm{t}_{\mathrm{t}-1}\right)$

Pressure-Sensitive Concentration $_{t-1}$

Pressure-Insensitive Concentration ${ }_{t-1}$

Tobin's $q_{\mathrm{t}-1}$

Market Capitalization $_{\mathrm{t}-1}$

CEO Dummy $\mathrm{t}_{\mathrm{t}}$

Number of observations

Adjusted $\mathrm{R}^{2}$

Wald F-statistic for equality of coefficients for Pressure-Sensitive versus Pressure-Insensitive

Total Direct Compensation $_{t}$

(1)

0.001

(1.44)

$-0.005^{\star * *}$

$(-10.10)$

$-277.838^{* * *}$ $(-35.85)$

$-320.466^{* * *}$

$(-47.06)$

$-20.108^{* * *}$

$(-28.74)$

$0.008^{* * *}$

(46.44)

$268.23^{* * *}$

(126.67)

36,346

0.45

$32.97^{\text {** }}$

(0.00)
(2)

$0.058^{\star \star \star}$

0.039 ***

$-2,277.654^{\star \star *}$

$-2,133.827^{\text {** }}$

$(-20.04)$

$-59.200^{\text {*** }}$

$0.045^{\text {*** }}$

$1,500.79^{* * *}$

33,278

0.18

1.55

(0.21) 


\section{Table VI}

\section{Pay-for-Performance Sensitivity as a Function of Institutional Influence Divided by Type of Institution}

Dependent variables: $\Delta$ (Salary Plus Bonus) or $\Delta$ (Total Direct Compensation)

This table shows the coefficients from a regression of the change in the manager's compensation against the lagged change in shareholder's wealth and the change in shareholder's wealth interacted with percentage holdings of institutions filing 13-f reports, holdings of top 5 institutions as a percent of institutional holdings (divided by type of institution) and controls for firm size (Market capitalization, net sales, total assets) and Tobin's $q$ ratio. Further control variables are a CEO dummy that equals one if the executive is CEO and 0 otherwise and a series of control dummies for the firm's two-digit SIC industry and for time. (The coefficients for the latter variables are not shown in the table.) T-statistics are provided in parentheses. One, two, and three asterisks denote significance at the $0.10,0.05$, and 0.01 levels, respectively.

Dependent variable:

$\underline{\text { Independent Variable }}$

$\Delta\left(\right.$ Shareholder wealth $\left.\mathrm{t}_{\mathrm{t}-1}\right)$

$\Delta\left(\right.$ Shareholder wealth $\mathrm{t}_{\mathrm{t}} \mathrm{X}$

Total $_{\mathrm{t}-1}$

Pressure-Sensitive Concentration $_{\mathrm{t}-1}$

Pressure-Insensitive Concentration $_{\mathrm{t}-1}$

Tobin's $q_{\mathrm{t}-1}$

Market Cap $_{\mathrm{t}-1}$

CEO Dummy
$\Delta($ Salary + Bonus ) $^{(}$

\section{$\Delta($ Total Direct \\ Compensation $n_{\mathrm{t}}$ )}

(1)

(2)

0.0003

0.084

(0.14)

$0.055^{\text {** }}$

$0.145^{\star \star *}$

(4.40)

(2.60)

0.001

$-0.010$

$(0.04)$

$(-0.12)$

$0.078^{\star \star *}$

(3.88)

$0.576^{* * *}$

$-0.003^{* * *}$

(6.40)

$(-4.05)$

$-0.003$

$(-0.92)$

$-0.142^{\star \star *}$

$-1.150^{\text {*** }}$

$(-3.35)$

$(-6.13)$

$0.023^{\star \star \star}$

$0.083^{* * *}$

(8.07)

(7.34)

36,346

27,612

0.01

0.04

Adjusted $\mathrm{R}^{2}$

$12.97^{\text {** }}$

$36.81^{* \star *}$

$(0.00)$

(0.00) 